Accepted Manuscript published at Elements Vol. 17, pp. 41-46

(DOI: 10.2138/gselements.17.1.41)

\title{
How climate, uplift and erosion shape the Alpine topography
}

3 Pierre G. Valla ${ }^{1,2}$, Pietro Sternai ${ }^{3}$ and Matthew Fox ${ }^{4}$

1. Institute of Earth Sciences (ISTerre), Univ. Grenoble Alpes, Univ. Savoie Mont Blanc, CNRS, IRD, IFSTTAR, 38000 Grenoble, France. E-mail: pierre.valla@univ-grenoble-alpes.fr

2. Institute of Geological Sciences, University of Bern, 3012 Bern, Switzerland

3. Department of Earth and Environmental Sciences, University of Milano-Bicocca, 20126 Milano,

9 Italy. E-mail: pietro.sternai@unimib.it

10 4. Department of Earth Sciences, University College London, WC1E 6BT London, UK. E-mail: 11 m.fox@ucl.ac.uk

\section{AbSTRaCT}

14 Decades of scientific research across the European Alps quantify the vast array of 15 processes shaping the Earth's surface. Developments in thermochronometry and terrestrial cosmogenic nuclides constrain spatial patterns of rock exhumation, surface erosion and topographic changes. These can be compared to sediments eroded from the Alps and preserved in surrounding sedimentary basins or collected from modern rivers. Erosion-driven isostatic uplift explains up to around $50 \%$ of the modern geodetic rock-uplift rates, revealing the importance of internal (tectonics, deep-seated geodynamics) and external (glacial rebound and topographic changes) processes. We highlight recent methodological and conceptual developments that have contributed to our present view of the European Alps, and suggest steps needed to fill gaps in our understanding.

\section{KEYWORDS}

Mountain geodynamics, erosion \& sediment yield, topographic evolution, climate and glaciations, geodetic uplift, modeling, geochronology

\section{INTRODUCTION}

31 Mountain topography lies at the interface between the Lithosphere and the 32 Hydrosphere/Biosphere, and its long-term evolution results from the interplay 33 between internal and external driving mechanisms (Fig. 1A, e.g. Whipple, 2009). 34 Internal forcing involves crustal thickening from tectonic shortening and deeper 35 processes such as lithospheric delamination or sub-lithospheric mantle flow. External 
Accepted Manuscript published at Elements Vol. 17, pp. 41-46

(DOI: 10.2138/gselements.17.1.41)

36 forcing is mainly characterized by climate, whose variability controls erosion and the building-melting of ice caps and glaciers, as well as the biota evolution and base-level changes, which all operate to redistribute material across the Earth's surface. Key components of this system are surface processes (Fig. 1A) which are central in regulating the interactions between internal and external drivers (Champagnac et al., 2014). Surface processes act in space and time directly on the Lithosphere (e.g. mass redistribution affecting the crustal stress field and thermal structure) and the Hydrosphere/Biosphere (e.g. erosion modulating rock weathering and carbon burial).

44 They shape mountain topography and relief, with indirect feedbacks on tectonics (topographic effects on the lithospheric stress and thermal state) and climate (orographic precipitation and large-scale atmospheric circulation controlled by mountain topography). A quantitative characterization of the mechanisms that control mountain topographic evolution is challenging, since they are intrinsically linked but also operate at different spatial and temporal scales $\left(10^{1}-10^{6}\right.$ meters or years), with thresholds and non-linear processes involved (Champagnac et al., 2014). The European Alps are a classic example of a mid-latitude convergent mountain belt, extending over $1000 \mathrm{~km}$ (Fig. 1B) and forming an arc-shape which can be divided into three main sectors: Western, Central and Eastern Alps (Schmid et al., 2004). The Alpine orogeny is the result of continent-continent collision between the European and Adriatic plates since the Late Eocene. The main topographic construction and rock exhumation, i.e. unroofing history or a rock's path towards Earth's surface, began at ca. $35 \mathrm{Ma}$ or earlier mostly driven by crustal thickening (Kuhlemann et al., 2002; Schmid et al., 2004). The main drainage organization and major drainage divide between Alpine sectors (Fig. 1B) were established relatively early in the orogeny, following the main tectonic structures (Figs. 1B), and are strongly influenced by the Early-Oligocene to Early-Miocene exhumation of crystalline massifs. The overall 62 Alpine topography reached high elevations during the early collisional stages, with 63 Early-Oligocene elevations similar to present-day in the Western Alps (as revealed by 64 palynology; Fauquette et al., 2015), and the high topography of the Central Alps was acquired during mid-Miocene times (from stable-isotope paleoaltimetry; Campani et al., 2012). It has been suggested that the topography of the Eastern Alps developed during Late Oligocene (Kuhlemann et al., 2002), but this has not yet been confirmed quantitatively. As a mid-latitude mountain range, and given their spatial extent, the European Alps are characterized by a variety of climatic regimes, with high spatial 
Accepted Manuscript published at Elements Vol. 17, pp. 41-46

(DOI: 10.2138/gselements.17.1.41)

A

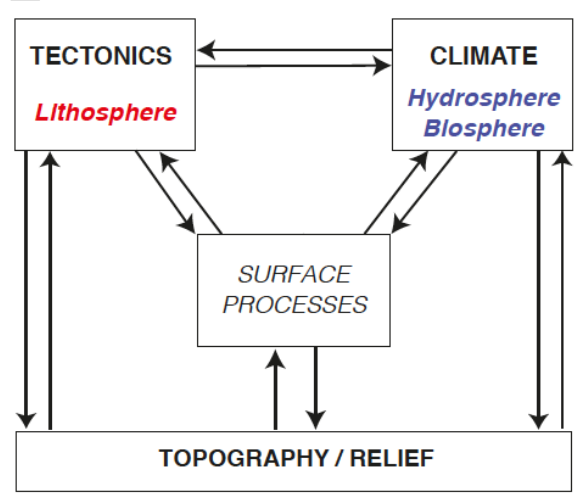

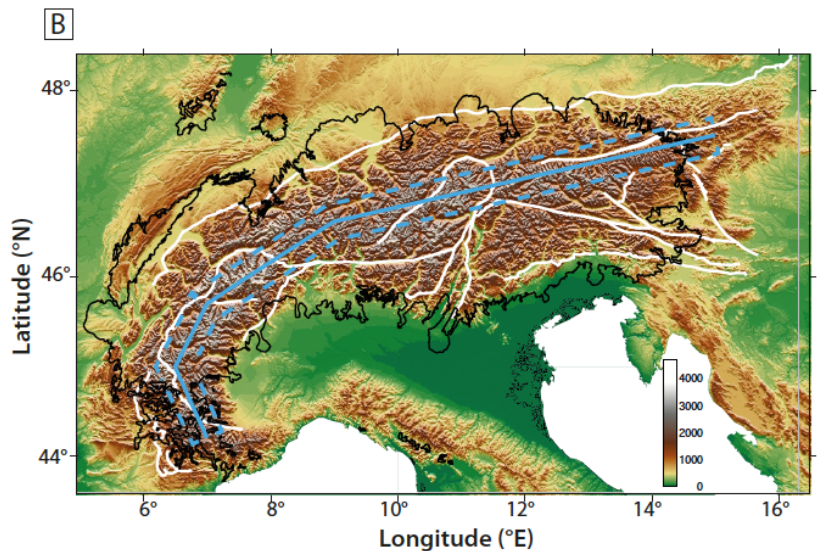

Figure 1. Alpine Topography \& Relief. (A) Sketch of the interplays and feedbacks between tectonics, climate and topography/relief in mountain evolution. This complex system involves interactions between the Lithosphere and the Hydrosphere and Biosphere, with surface processes regulating the interactions (details on these are presented in the original figure of Champagnac et al., 2014). (B) Modern topography of the European Alps (90-m resolution DEM) with Last Glacial Maximum (LGM) ice extent (white lines; Ehlers and Gibbard, 2004), major Alpine tectonic lineaments (Schmid et al., 2004) and swath profile (thick and dashed blue lines). 
Accepted Manuscript published at Elements Vol. 17, pp. 41-46

(DOI: 10.2138/gselements.17.1.41)

97

98

99

100

101

102

103

104

105

106

107

108

109

110

111

112

113

114

115

116

117

118

119

120

121

122

123

124

125

126

127

128

129

130

Here, we review some key pieces of evidence constraining the topographic evolution of the European Alps. We present how methodological developments, especially regarding topographic, geochronologic and modeling methods, have quantified longterm erosion and relief development. Such a quantitative framework is needed to assess the relative contributions of internal and external forcing in the evolution of the European Alps, and to diagnose the potential drivers for modern rock-uplift patterns observed along the Alpine arc.

\section{OLigocene-Miocene eVOLUTiOn OF THE AlPS}

The main Alpine collisional phase started at ca. $35 \mathrm{Ma}$, with the rapid development of mountainous topography, major drainage reorganization (Lu et al., 2018), and onset of sediment production on both the pro- (northern) and retro- (southern) sides of the orogen (Kuhlemann et al., 2002; Fox et al., 2016). Sedimentary basins surrounding the European Alps offer a crucial archive to reconstruct the evolution of sediment yield during mountain building. The main challenges when using sediment records as proxies for long-term erosion history are (1) sediment preservation and possible remobilization after deposition or the recycling of sedimentary rocks during orogenesis, (2) changes in the river drainage patterns (i.e. inferred link between sediment deposits and original relief sources), and (3) chemical erosion and the importance of dissolved load in the total erosion budget. Figure 2A presents a compilation of erosion products for the European Alps (Kuhlemann et al., 2002), showing two main periods in the sediment yield history (35-15 Ma and 15-0 Ma, Fig. 2A). There is a significant increase in sediment yield between ca. 30 and $25 \mathrm{Ma}$, reflecting topographic building and relief development allowing the onset of active geomorphic processes and efficient sediment production. Between 25 and $15 \mathrm{Ma}$, sediment yields remained high and have been punctuated by short pulses which are proposed to reflect changes in tectonic forcing and movements of the drainage divide (Kuhlemann et al., 2002). The mobility of the drainage divide is also evidenced by antagonistic trends in sediment discharge between the Northern and Southern Alps. This 25-15 Ma period is considered the main tectonic constructional phase of the European Alps (especially for the Eastern Alps). The 15-5 Ma phase is characterized by a significant decrease in sediment yield just before 15 Ma for both the Western/Central and Eastern Alps, followed by steady sediment flux for the Western and Central Alps. For the Eastern 
Accepted Manuscript published at Elements Vol. 17, pp. 41-46

(DOI: 10.2138/gselements.17.1.41)

131 Alps, a minor increasing trend can be observed during the mid-Miocene. Finally, the most striking observation from Kuhlemann et al. (2002) is the significant increasing

133 trend beginning at ca. 5 Ma (Miocene/Pliocene transition, Fig. 2A), observed for the 134 entire European Alps but apparently more important for the Western and Central 135 Alps.
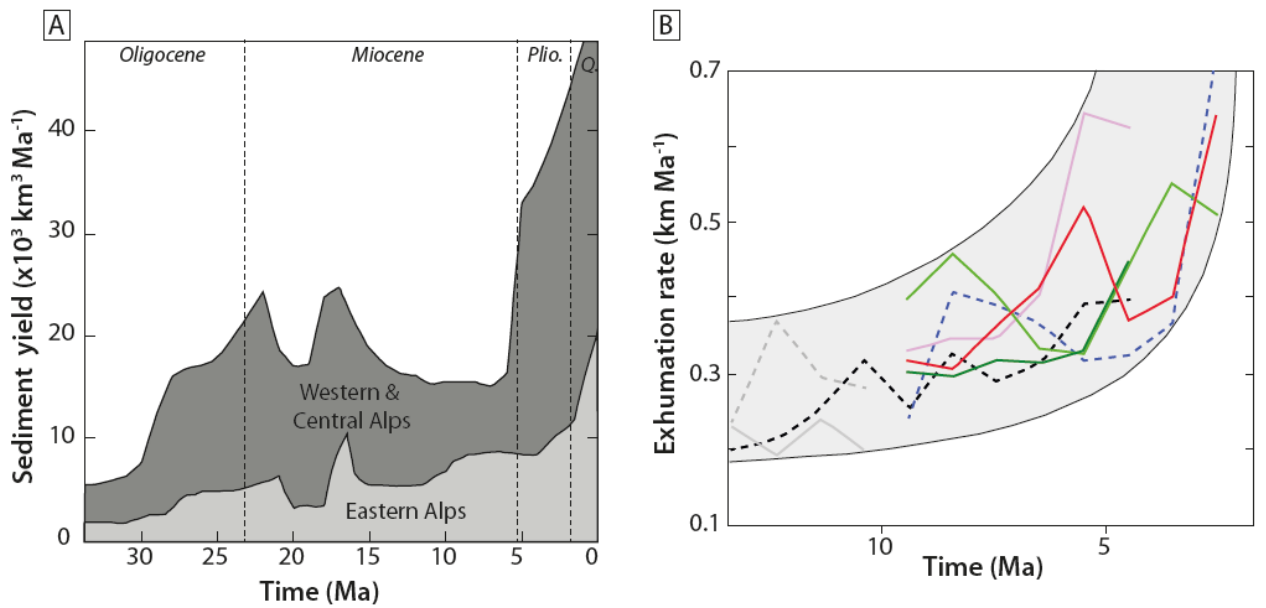

C
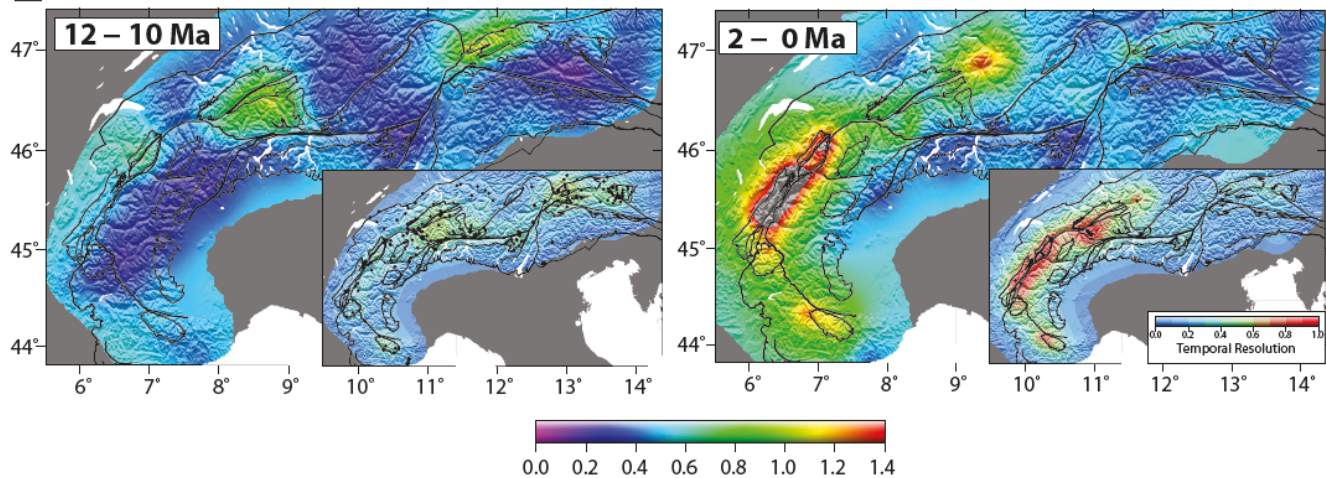

Exhumation Rate $\left(\mathrm{km} \mathrm{Ma}^{-1}\right)$

138 Figure 2. Erosion \& Sediment Fluxes. (A) Late-Cenozoic sediment budgets for the Eastern and Western/Central (including Southern) Alps, after Kuhlemann et al. (2002). Exhumation of Western (thick colored lines) and Central (dashed colored lines) Alps, extracted from geometric reconstruction of bedrock thermochronometric isoages (Vernon et al., 2008). Note the overall increase trend (grey envelope) in exhumation since ca. $5 \mathrm{Ma}$, similar to sediment yield trends shown in (A). (C) Spatial distribution of Alpine exhumation from linear inversion of thermochronomotric data. 12-10 Ma (left) and 2-0 Ma (right) time windows are presented for illustration of the temporal variability (insets show temporal resolution for each time window). Black lines indicate main Alpine massifs and tectonic lineaments (Schmid et al., 2004). Based on Fox et al. (2016). 
Accepted Manuscript published at Elements Vol. 17, pp. 41-46

(DOI: 10.2138/gselements.17.1.41)

149 Sediment yield records indicate that Alpine orogeny has experienced major changes

150 in topographic and erosion histories. However, given the large-scale spatial

151 integration of sediment records, assessing the spatio-temporal patterns in erosion at

152 massif scale has remained challenging. Thermochronometry records the time since a

153 rock passed through an effective closure temperature, and can provide a direct

154 quantification of rock exhumation towards Earth's surface driven by erosion and

155 tectonic unroofing. In addition, the thermal field of the upper crust is also sensitive to

156 rock uplift and surface topography (i.e. amplitude and wavelength). Low-temperature

157 thermochronometry (apatite and zircon thermochronometers, i.e. with closure

158 temperatures $<250{ }^{\circ} \mathrm{C}$ ) can be used to quantify rock exhumation, at a timescale

159 provided by the respective rock cooling ages. Detrital thermochronometry, from

160 modern river sediments or past sediment records, provides an integrated overview of

161 Alpine long-term erosion. Despite fragmentary records for the early construction

162 stages, detrital thermochronometry confirms erosion pulses during the Oligocene but

163 suggests an overall steady erosion over the European Alps since ca. $15 \mathrm{Ma}$ at rates of

164 0.1-0.4 $\mathrm{km} \mathrm{Ma}^{-1}$ (Bernet et al., 2001). Within this apparent steady setting, detrital

165 thermochronometry has also revealed major changes in sediment provenance that

166 reflect re-organization of river drainage patterns for the Eastern Alps (around $20 \mathrm{Ma}$ )

167 and Western/Central Alps (around 13-10 Ma), in agreement with sediment records

168 (Kuhlemann et al., 2002).

169 Bedrock thermochronometry provides direct quantification of erosion and topographic

170 history. Since the 1970's, over 3000 bedrock cooling ages (including multi-

171 thermochronometers) have been acquired across the Alps, providing dense datasets

172 for extracting exhumation patterns in space and time (Vernon et al., 2008; Fox et al.,

173 2016). Bedrock thermochronometry suggests early onset of erosion in the Eastern

174 Alps (Tauern window and Austroalpine units) and Southern Alps (Bergell and

175 Adamello massifs), with Early- to mid-Miocene erosion pulses linked to tectonic

176 shortening and crustal thickening, followed by overall moderate erosion magnitudes

177 since the mid-Miocene. A Late-Miocene erosion increase has also been documented

178 for the Southern Alps, while this has not been observed with bedrock

179 thermochronometry in the Eastern Alps. In the Western and Central Alps,

180 thermochronometric data highlight exhumation contrasts, with mid-Miocene erosion

181 onset linked to the exhumation of the External Crystalline Massifs (Aar-Gotthard,

182 Mont-Blanc, Belledonne-Pelvoux; Schmid et al., 2004) and within more internal parts 
Accepted Manuscript published at Elements Vol. 17, pp. 41-46

(DOI: 10.2138/gselements.17.1.41)

183 of the orogen (Lepontine Dome), followed by an apparent major increase in erosion 184 during the Late Miocene (Fig. 2B). This ca. 5-Ma erosion signal, similar to the sediment record (Fig. 2A), has raised long-lasting discussions about the potential contributions of tectonics $v s$. climate in late-stage erosion dynamics of the European Alps. For the Western and Central Alps, both hypotheses have been postulated with an orogen response to (1) a climate shift at the Miocene-Pliocene transition, with enhanced climatic variability and possibly increased precipitation favoring efficient geomorphic processes and sediment production/export (e.g. Vernon et al., 2008), (2) deep-seated geodynamic processes such as lithospheric slab detachment (e.g. Fox et al., 2015). For the Eastern Alps, limited post-Miocene rock uplift and erosion has

193 been documented, although not recorded by thermochronometry, and related to 194 changes in regional tectonics (i.e. inversion of Pannonian Basin; e.g. Ruszkiczay195 Rüdiger et al., 2020 and references therein).

196 Recent numerical developments in thermal(-kinematic) models and inversion 197 approaches (e.g. Fox et al., 2016; Fig. 2C) have allowed researchers to include multi198 thermochronometers for assessing bedrock erosion histories. For the Western and 199 Central Alps, these methods have revealed a more complex erosion framework. There 200 is evidence for mid-Miocene onset of high erosion rates (Fig. 2C) with tectonic uplift 201 from crustal thickening, but also for a subsequent decrease in erosion towards the Late 202 Miocene-Early Pliocene. Temporal erosion trends from bedrock thermochronometry 203 (Fig. 2C) and sediment yield records (Fig. 2A) slightly differ for the Late Miocene. 204 The progressive exhumation and exposure of crystalline and highly-resistant rocks at 205 this time could have caused an overall decrease in bedrock erosion (lower erodibility) while increasing the relative abundance of crystalline clasts (better preservation) in 207 the sediment record. Finally, inversion of bedrock thermochronometry reveals a major 208 increase in erosion since ca. 2 Ma (Fig. 2C) for the Western/Central Alps, although 209 the resolution of both current thermochronometric data and imaging of the Earth's 210 interior via inversion of seismic data cannot be used to distinguish between either 211 tectonics or climate forcing, nor to recognize feedbacks triggering this erosion 212 increase (Fox et al., 2015).

\section{Alpine topography \& Pliocene-Quaternary glaciation}

215 Alpine landscapes present typical glacial landforms with glacial cirques, U-shaped 216 wide, steep and deep valleys (Fig. 1B), but also "hidden" landscape features such as 
Accepted Manuscript published at Elements Vol. 17, pp. 41-46

(DOI: 10.2138/gselements.17.1.41)

217 overdeepnings which form major lakes and sediment infills in the present-day

218 topography. Although the Quaternary geomorphic imprint of glacial erosion is

219 obvious, key questions remain regarding its timing, magnitude and spatial variability.

220 Is landscape transition from fluvial to glacial landforms a rapid process that occured

221 during the early glaciations? How variable are spatial patterns and rates in glacial

222 erosion between different glacial periods? Are fluvial features (such as inner gorges

223 and hanging valleys) markers of post-glacial landscape re-adjustment or do they

224 evolve through multiple glacial/interglacial cycles? Numerical outcomes suggest that

225 glacial erosion in the Western/Central Alps has propagated from low to high

226 elevations during the successive glacial periods, as the landscape evolved from fluvial

227 to glacial conditions (Sternai et al., 2013). However, quantifying via observations the

228 impact of Plio-Quaternary glaciation on Alpine erosion and topography has remained

229 difficult due to (1) the relatively short timescales involved (1-2 Ma for the Quaternary

230 and 10-100 ka for individual glacial/interglacial cycles) compared to the current

231 resolution of thermochronometric methods, and (2) the preservation of, and/or access

232 to, continuous sedimentary records or geomorphic markers for individual glaciations.

233 For the European Alps, the onset of major glaciation follows the Northern

234 Hemisphere glaciation (ca. $3 \mathrm{Ma}$ ), with a major environmental and stratigraphic

235 change reported at ca. 0.9 Ma (e.g. Muttoni et al., 2003). Previous Plio-Quaternary

236 glacial phases would have been of limited extent, leaving only scarce sediment

237 records in the internal parts of the Alpine massifs. The mid-Pleistocene transition

238 (MPT, ca. 1.2 Ma) promoted global climate change with the switch from low-

239 amplitude short (symmetric 40-ka) to high-amplitude long (asymmetric 100-ka)

240 glacial/interglacial cycles. For the European Alps, this MPT change would have

241 resulted in the development of extensive and long-lasting glaciers that reached the

242 Alpine forelands (Muttoni et al., 2003).

243 In the Western/Central Alps, there is quantitative evidence for the impact of glaciation

244 on Alpine topography (Fig. 3A). In the Swiss Central Alps, Haeuselmann et al. (2007)

245 have used cosmogenic ${ }^{26} \mathrm{Al} /{ }^{10} \mathrm{Be}$ dating of buried cave sediments to quantify the Aare

246 valley deepening with respect to the cave system. Dating results show two valley

247 deepening periods over the Plio-Quaternary, with limited deepening (at $\sim 0.1 \mathrm{~km} \mathrm{Ma}^{-1}$ )

248 until ca. $0.9 \mathrm{Ma}$ followed by abrupt valley deepening (at $>1 \mathrm{~km} \mathrm{Ma}^{-1}$ ). In the upper

249 Rhône valley (Swiss Western Alps), Valla et al. (2011) used apatite ${ }^{4} \mathrm{He} /{ }^{3} \mathrm{He}$

250 thermochronometry to quantify the late-stage bedrock cooling along the valley flank. 
Accepted Manuscript published at Elements Vol. 17, pp. 41-46

(DOI: 10.2138/gselements.17.1.41)

251 Using geothermal constraints and thermal-kinematic modeling, their results highlight a quiescent erosion phase during Plio-Quaternary followed by subsequent valley incision (i.e. topographic change by spatially-focused erosion) at $1 \mathrm{~km} \mathrm{Ma}^{-1}$ since ca. $1 \mathrm{Ma}$ (Fig. 3A). These outcomes not only point towards a major erosional shift since around $1 \mathrm{Ma}$ for the Western/Central Alps, but also reveal a topographic change with significant relief increase that is interpreted as glacial valley deepening. Such a topographic response to glaciation has not been observed or with limited magnitude for the Eastern and Southern Alps, despite similar glacial landforms with deep and wide U-shaped valleys (Sternai et al., 2012). Pre-glacial topographic reconstructions have been attempted using different methods, such as the geophysical relief approach

261 (Champagnac et al., 2014) or by computing a steady-state fluvial topography (Sternai 262 et al., 2012) with subsequent modifications by glacial processes. Although these 263 models rely on a number of untestable (but plausible) assumptions (e.g. constant 264 drainage network throughout the Quaternary), they provide useful first-order 265 estimates for evaluating glacial topographic changes in the European Alps (Fig. 3B) and the associated isostatic response to non-steady erosional unloading (Fig. 5).

267 Moreover, these results raise new contradictory observations and questions: 268 topographic changes appear similar to slightly more pronounced for the Eastern Alps 269 (Fig. 3B) than in the Western and Central Alps, whereas bedrock thermochronometry 270 suggests significantly different trends for long-term erosion (Figs. 2C and 3B). Such 271 observations cannot be explained by horizontal shortening, which has been limited in 272 the Western/Central Alps and is ongoing in the Eastern Alps. One alternative 273 mechanism could be the occurrence of deep geodynamic forcing (e.g. sub-lithospheric 274 mantle flow) sustaining relatively high steady erosion in the Western and Central Alps 275 compared to the Eastern Alps (Fox et al., 2015; Sternai et al., 2019). The observed 276 differences (Fig. 3B) between Plio-Quaternary erosion estimates and Quaternary 277 topographic changes would call for further research to quantify the respective 278 contributions from "steady" (i.e. driven by rock uplift) erosion and "non-steady" 279 topographic evolution of the European Alps. 
Accepted Manuscript published at Elements Vol. 17, pp. 41-46

(DOI: 10.2138/gselements.17.1.41)
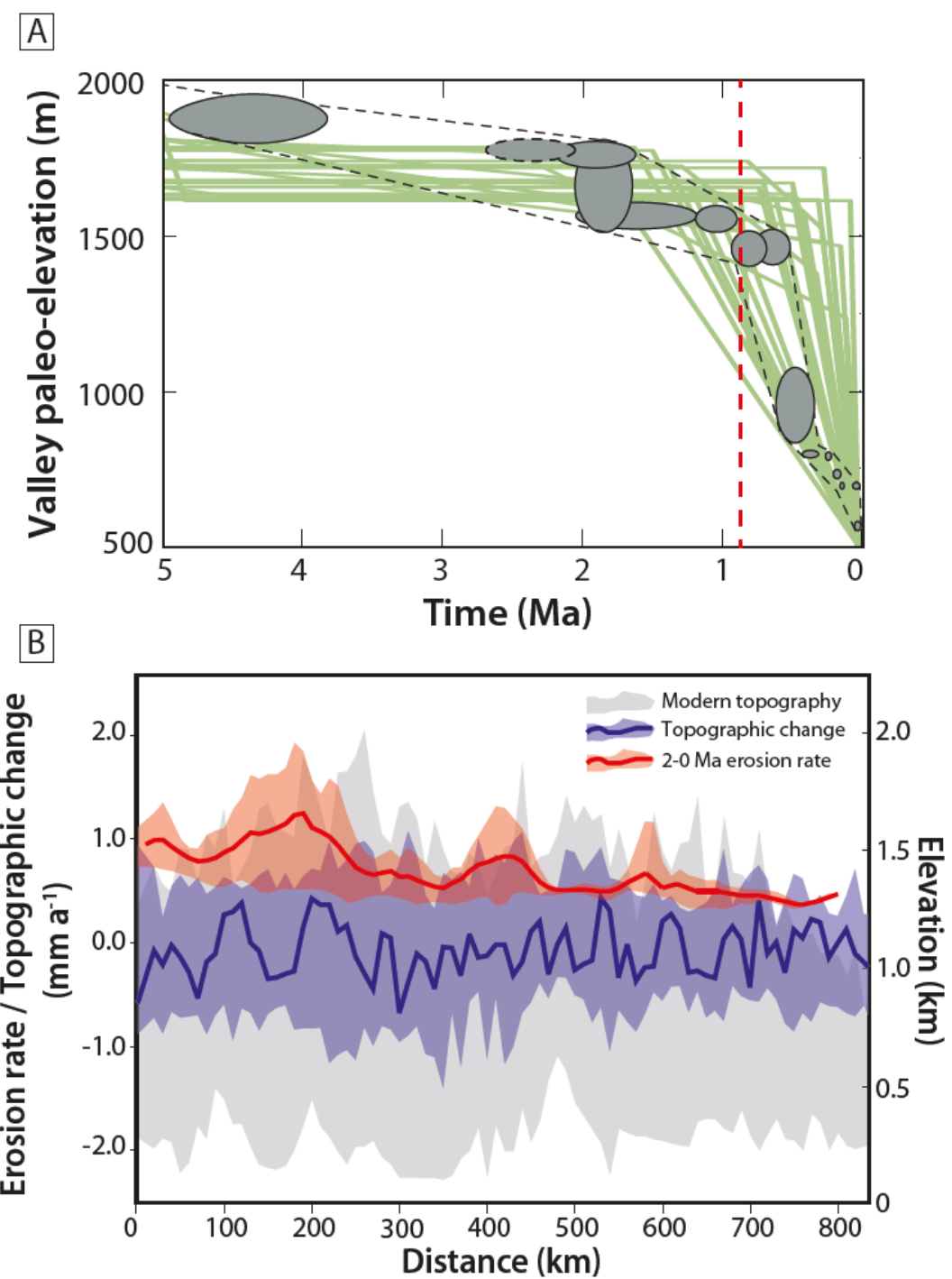

282 Figure 3. Plio-Quaternary Erosion \& Relief Development. (A) Paleo-elevation (proxy for 283 valley incision) of the Aare (dating of cave sediments, grey ellipses and black dashed lines; 284 Haeuselmann et al., 2007) and Rhône (bedrock low-temperature thermochronometry, 285 converted into valley floor paleo-elevations using thermal-kinematic modeling, green lines; 286 Valla et al., 2011) valleys. Red dashed line indicates onset of major Alpine glaciation from stratigraphic evidence (Po River Basin; Muttoni et al., 2003). (B) Swath (see Fig. 1B for location) profiles of modern topography (Fig. 1B, grey envelope), 2-0 Ma erosion rate (Fig. 2C, red line and envelope) and topographic change over the last $1 \mathrm{Ma}$ (Sternai et al., 2012; blue line and envelope).

\section{MODERN ROCK UPLIFT AND EROSION: CAUSES AND IMPLICATIONS}

293 The modern European Alps are characterized by limited shortening in the Western 294 and Central Alps, and by ongoing active shortening in the Eastern Alps. In contrast, geodetic (leveling, GPS/GNSS) rock-uplift rates, averaged over the last 10 to 100 
Accepted Manuscript published at Elements Vol. 17, pp. 41-46

(DOI: 10.2138/gselements.17.1.41)

296 years, are highest in the Western and Central Alps (up to around $2 \mathrm{~mm} \mathrm{a}^{-1}$, Fig. 5;

297 Nocquet et al., 2016; Sternai et al., 2019). What is driving the observed spatial

298 patterns of rock uplift in the European Alps? Erosion rates have been invoked to

299 explain these rock-uplift patterns, but their spatial and temporal quantification is

300 required to recognize whether the European Alps are actually experiencing or not

301 surface uplift.

302 Modern erosion for the European Alps has been estimated using sediment yield (river 303 and reservoir gauges; Hinderer et al., 2013) and cosmogenic ${ }^{10} \mathrm{Be}$ (riverine sediments,

304 Delunel et al., 2020) for the main drainage basins across the Alps. Modern sediment 305 yield data cover the last decades and combine physical and chemical erosion. The 306 spatial distribution of modern Alpine erosion shows a $\sim 3$ fold difference in erosion 307 between the Western/Central Alps and the Eastern Alps, which is interpreted as 308 reflecting enhanced chemical erosion of carbonate sedimentary rocks that are 309 abundant in the external mountainous parts of the Western/Central Alps (Hinderer et 310 al., 2013). Cosmogenic ${ }^{10}$ Be-derived erosion yields millennial integration timescales 311 and presents similar patterns, with higher erosion in the Western/Central Alps ( 2-3 312 fold difference, Fig. 4) compared to the Eastern Alps. Moreover, both erosion datasets 313 show no evidence for a modern climatic control (i.e. present-day precipitation 314 patterns) on the spatial erosion distribution, but they rather reveal a significant 315 slope/relief control on erosion which reflects intense glacial pre-conditioning of the 316 Alpine topography as well as ongoing glacier retreat (Hinderer et al., 2013; Delunel et 317 al., 2020). Millennial to modern erosion patterns indeed follow an expected 318 geomorphic response since the last glacial maximum (ca. $20 \mathrm{ka}$ ago), characterized by 319 high post-glacial erosion rates and transient hillslope and fluvial topographic re320 adjustment. It remains debated how long landscapes take to switch from glacial to 321 fluvial conditions, and this response may take multiple interglacial periods (e.g. 322 Montgomery and Korup, 2010; Leith et al., 2018).

323 Both modern geodetic rock-uplift rates and erosion-rate patterns (derived from 324 sediment yield and cosmogenic ${ }^{10} \mathrm{Be}$ ) present a similar increasing trend from the 325 Western to Central Alps followed by a decrease towards the Eastern Alps, suggesting 326 the existence of a functional relationship, with the proposed hypothesis of erosion327 driven rock uplift for the European Alps (Champagnac et al., 2009). However, while 328 patterns do correlate, modern erosion rates are generally lower than modern rock329 uplift rates (Fig. 4), implying that the isostatic response to erosional mass removal 
Accepted Manuscript published at Elements Vol. 17, pp. 41-46

(DOI: 10.2138/gselements.17.1.41)

330 cannot explain all the observed rock-uplift rates. This discrepancy may result from the

331 different spatial and temporal scales covered by erosion and rock-uplift datasets,

332 which can be problematic when extrapolating yearly to decadal sediment yield,

333 climatic data and geodetic rock-uplift estimates to thousand-year timescales which are

334 representative of cosmogenic ${ }^{10} \mathrm{Be}$-derived erosion rates. An alternative explanation

335 for the observed discrepancy between modern rock-uplift and erosion patterns, if any

336 relationship between them should exist, could be that modern rock uplift integrates

337 different external or internal contributions along the European Alps (Sternai et al.,

338 2019). In Figure 5, we evaluate the spatial patterns of both the modern geodetic uplift

339 and the respective contributions of external (i.e. deglaciation rebound and erosion-

340 induced elastic adjustment) and internal (dynamic uplift from mantle flow) forcing

341 mechanisms. These estimates are based on various assumptions, such as the sub-

342 lithospheric mantle viscosity and lateral/depth variations, the timing and spatial

343 variability in deglaciation or the importance of topographic change $v$ s. steady

344 background erosion for erosional unloading across the European Alps (see extended

345 discussion in Sternai et al., 2019). For the Eastern Alps, the combination of erosional

346 response and deglaciation rebound (external forcing) matches the geodetically-

347 measured uplift, suggesting isostatic adjustment could be the only mechanism for

348 uplift in this region. However, this scenario is unlikely since (1) the Eastern Alps are

349 still experiencing shortening and associated tectonic uplift, as also suggested by local

350 examples of inversion tectonics since ca. 3 Ma (e.g. Ruszkiczay-Rüdiger et al., 2020);

351 in addition, (2) mantle upwelling below and sediment loading within the Pannonian

352 Basin are likely to involve, respectively, dynamic uplift and subsidence in the Eastern

353 Alps (Fig. 5). Modern limited rock uplift in the Eastern Alps thus appears to us as the

354 result of a combination of opposing forcings. For the Western and Central Alps, the

355 isostatic response to deglaciation and erosional unloading contributes up to around

$35650 \%$ of the observed geodetic rock uplift (Fig. 5). Given the limited tectonic

357 shortening occurring in these regions, deeper mechanisms involving lithospheric and

358 sub-lithospheric mantle flow (and related dynamic uplift) must be at play. Convective

359 processes from lithospheric slab detachment below the Western Alps are particularly

360 debated (Lippitsch et al., 2003; Zhao et al., 2016), since the occurrence, timing and

361 spatial extent of such event(s) are still poorly constrained. For the Central Alps, the

362 sub-lithospheric mantle flow contribution to rock uplift appears significant (Fig. 5), 
Accepted Manuscript published at Elements Vol. 17, pp. 41-46

(DOI: 10.2138/gselements.17.1.41)

363 and can explain the high observed rock-uplift rates (up to $2 \mathrm{~mm} \mathrm{a}^{-1}$ ) when combined

364 with the isostatic adjustments to external forcing.

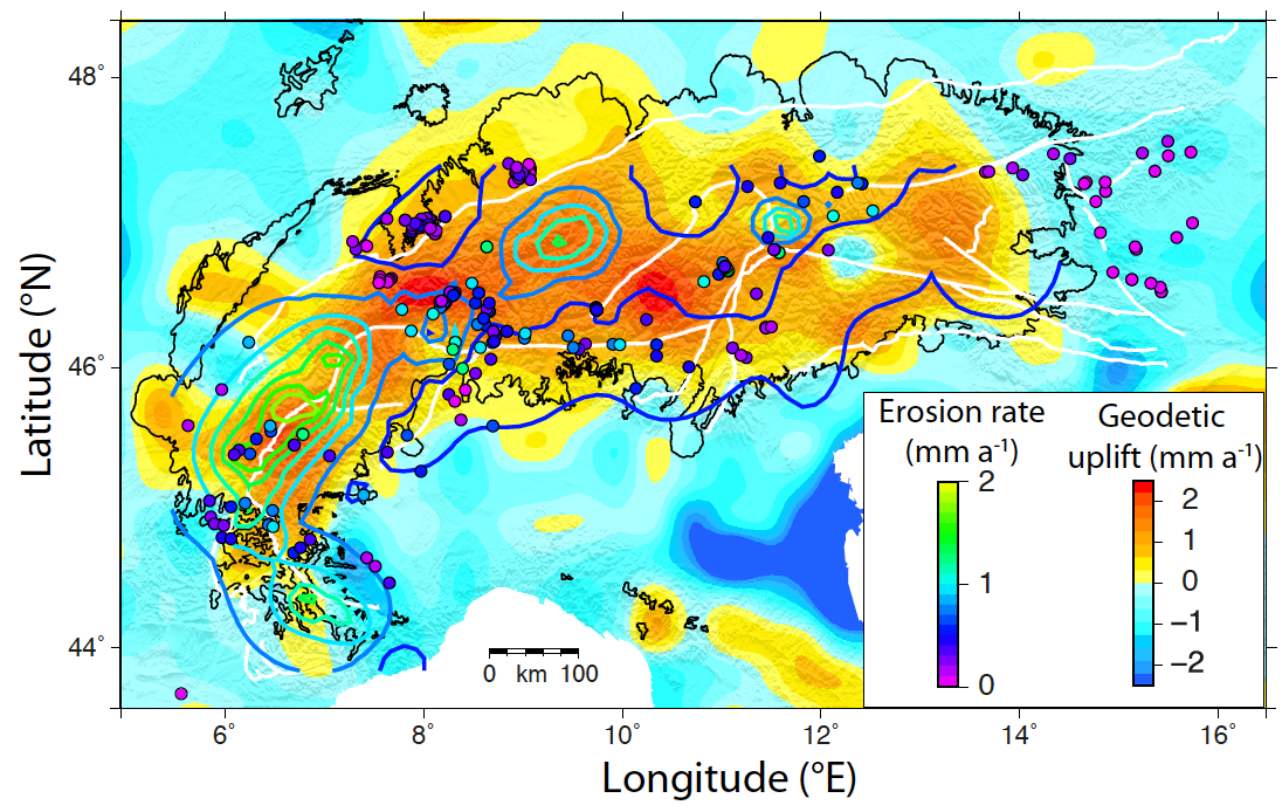

Figure 4. Modern Rock Uplift \& Erosion. Spatial distribution (30-km resolution) of modern geodetic rock uplift (Sternai et al., 2019) over decadal timescales. Colored circles are catchment outlets for cosmogenic ${ }^{10} \mathrm{Be}$-derived erosion estimates over millennial timescales (Delunel et al., 2020). Colored lines are 2-0 Ma erosion estimates from linear inversion of thermochronometric data (Fox et al., 2016). Black and white lines are LGM ice extent and major Alpine tectonic lineaments, respectively.

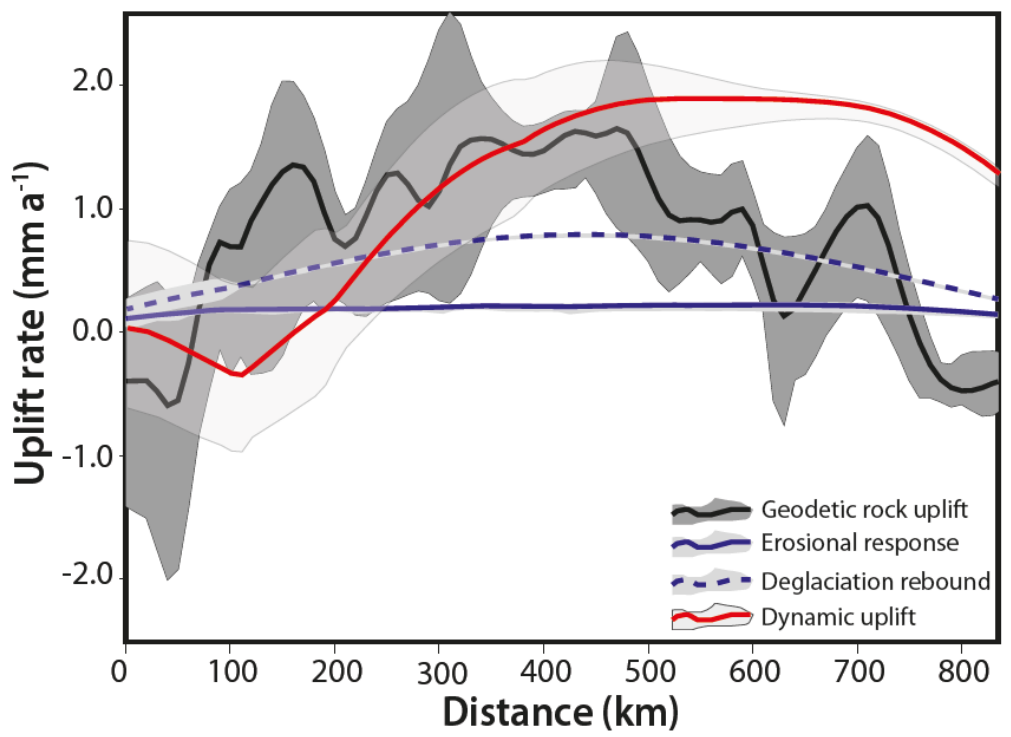

Figure 5. Modern Geodetic Uplift \& Potential Uplift Contributions. Swath (see Fig. 1B for location) profiles of modern geodetic rock uplift (Fig. 4, black line and dark-grey envelope), 
Accepted Manuscript published at Elements Vol. 17, pp. 41-46

(DOI: 10.2138/gselements.17.1.41)

377

378

379

external (erosional adjustment from topographic changes and deglaciation rebound, blue plain and dashed lines respectively with grey envelopes; Sternai et al., 2012; Spada et al., 2009) and internal (dynamic uplift, red line and light-grey envelope; Zhao et al., 2016) forcing mechanisms. The different contributions are sourced from Sternai et al. (2019).

\section{SUMMARY \& OUTLOOK}

Our review of Late-Cenozoic evolution of the European Alps is based on different methodologies, ranging from sediment yield analyses (modern and past records), geochronology (mainly low-temperature thermochronometry and terrestrial cosmogenic nuclides) and geodesy or geophysics combined with numerical modeling. This method diversity allows us to assess the different spatial and temporal scales involved with Alpine erosion and topographic evolution. The existing data show a complex spatio-temporal evolution of the European Alps, with onset of topographic construction in the Early Oligocene, and significant tectonic controls on erosion and topographic building via crustal thickening and drainage pattern changes until the mid-Miocene. Plio-Quaternary erosion and topographic evolution appear to be controlled by climatically-driven geomorphic processes, with major glaciation impact on topography since ca. $1 \mathrm{Ma}$ in the Western and Central Alps, but apparently not in the Eastern Alps. In addition, there is a spatial contrast in both modern erosion and geodetic rock uplift between the Western/Central and Eastern Alps. This strongly suggests that the late-stage evolution of the European Alps is reflecting the interplay between external (climate) and internal (solid Earth) mechanisms. Future studies need to provide higher resolution in thermochronometric data for late-stage erosion of slowly-eroding regions, where current data only provide average erosion histories over long periods. This will be possible with the recent development of very lowtemperature thermochronometers. In addition, further geomorphic markers and sediment archives need to be investigated and dated to improve the existing chronology for the progressive (or not) Alpine topographic evolution and for glacier fluctuations (timing and extent) during previous glacial/interglacial cycles of the PlioQuaternary. Such improvements would provide a quantitative framework for the recent erosion history of the Alps, which is required to estimate the isostatic response to erosional unloading, considering both steady background erosion and topographic changes, in addition to deglaciation. Finally, sub-lithospheric mantle flow and potential slab detachment are likely to contribute to the modern geodetic rock uplift. 
Accepted Manuscript published at Elements Vol. 17, pp. 41-46

(DOI: 10.2138/gselements.17.1.41)

411 Higher-resolution tomographic models would provide important information for

412 further constraining these contributions across the European Alps.

\section{ACKNOWLEDGMENTS}

415 P.G.V. acknowledges funding from the French ANR-PIA program (ANR-18- MPGA416 0006) and the Swiss SNSF (PP00P2_170559). P.S. was supported by the Italian 417 Ministry of Education MIUR (Rita Levi Montalcini, DM 694-26/2017, and 418 Dipartimenti di Eccellenza 2018-2022 grants). M.F. is supported by NERC 419 (NE/N015479/1). The authors warmly thank B. Salcher, K. Whipple and an 420 anonymous reviewer for their constructive and insightful reviews, as well as the 421 editors A. McCarthy and O. Müntener for their invitation and suggestions.

\section{REFERENCES}

424 Bernet M, Zattin M, Garver JI, Brandon MT, Vance JA (2001) Steady-state exhumation of the European Alps. Geology 29: 35-38

Campani M, Mulch A, Kempf O, Schlunegger F, Mancktelow N (2012) Miocene paleotopography of the central Alps. Earth and Planetary Science Letters 337-338: 174185

Champagnac J-D, Valla PG, Herman F (2014) Late-Cenozoic relief evolution under evolving climate: A review. Tectonophysics 614: 44-65

Champagnac JD, Schlunegger F, Norton K, von Blanckenburg F, Abbühl LM, Schwab M (2009) Erosion-driven uplift of the modern Central Alps. Tectonophysics 474: 236-249

Delunel R, Schlunegger F, Valla PG, Dixon J, Glotzbach C, Hippe K, Kober F, Molliex S, Norton KP, Salcher B, Wittmann H, Akçar N, Christl M (2020) Late-Pleistocene catchment-wide denudation patterns across the European Alps. Earth-Science Reviews 211: 103407.

Ehlers J, Gibbard PL (2004) Quaternary glaciations-extent and chronology: part I: Europe. Elsevier: 488pp

Fauquette S, Bernet M, Suc JP, Grosjean AS, Guillot S, van der Beek P, Jourdan S, Popescu SM, Jiménez-Moreno G, Bertini A, Pittet B,Tricart P, Dumont T, Schwartz S, Zheng Z, Roche E, Pavia G, and Gardien V (2015) Quantifying the Eocene to Pleistocene topographic evolution of the southwestern Alps, France and Italy. Earth and Planetary Science Letters 412: 220-234

Fox M, Herman F, Kissling E, Willett SD (2015) Rapid exhumation in the Western Alps driven by slab detachment and glacial erosion. Geology 43: 379-382 
Accepted Manuscript published at Elements Vol. 17, pp. 41-46

(DOI: 10.2138/gselements.17.1.41)

Fox M, Herman F, Willett SD, Schmid SM (2016) The exhumation history of the European Alps inferred from linear inversion of thermochronological data. American Journal of Science 316: 505-541

Haeuselmann P, Granger DE, Jeannin PY, Lauritzen SE (2007) Abrupt glacial valley incision at $0.8 \mathrm{Ma}$ dated from cave deposits in Switzerland. Geology 35: 143-146

Hinderer M, Kastowski M, Kamelger A, Bartolini C, Schlunegger F (2013) River loads and modern denudation of the Alps-a review. Earth Sci. Rev. 118: 11-44

Kuhlemann J, Frisch W, Székely B, Dunkl I, Kazamér M (2002) Post-collisional sediment budget history of the Alps: tectonic versus climatic control. Int. J. Earth Sci. 91: 818-837

Leith K, Fox M, Moore JR (2018) Signatures of Late Pleistocene fluvial incision in an alpine landscape. Earth and Planetary Science Letters 483: 13-28

Lippitsch R, Kissling E, Ansorge J (2003) Upper mantle structure beneath the Alpine orogen from high-resolution teleseismic tomography. J. Geophys. Res. 108: B8

Lu G, Winkler W, Rahn M, von Quadt A, Willett SD (2018) Evaluating igneous sources of the Taveyannaz formation in the Central Alps by detrital zircon $\mathrm{U}-\mathrm{Pb}$ age dating and geochemistry. Swiss J Geosci 111: 399-416

Montgomery DR, Korup O (2010) Preservation of inner gorges through repeated Alpine glaciations. Nat. Geosci. 4: 62-67.

Muttoni G, Carcano C, Garzanti E, Ghielmi M, Piccin A, Pini R, Rogledi S, Sciunnach D (2003) Onset of major Pleistocene glaciations in the Alps. Geology 31: 989-992

Nocquet JM, Sue C, Walsperdorf A, Tran T, Lenotre N, Vernant P, Cushing M, Jouanne F, Masson F, Baize S, Chery J (2016) Present-day uplift of the western Alps. Sci. Rep. 6: 28404

Ruszkiczay-Rüdiger Z, Balázs A, Csillag G, Drijkoningen G, Fodor L (2020) Uplift of the Transdanubian Range, Pannonian Basin: How fast and why?. Global and Planetary Change 192: 103263.

Schmid SM, Fugenshuh B, Kissling E, Schuster R (2004) Tectonic map and overall architecture of the Alpine orogen. Eclogae Geol. Helv.: 93-117

Serpelloni E, Vannucci G, Anderlini L, Bennett RA (2016) Kinematics, seismotectonics and seismic potential of the eastern sector of the European Alps from GPS and seismic deformation data. Tectonophysics 688: 157-181

Spada G, Stocchi P, Colleoni F (2009) Glacio-isostatic adjustment in the Po plain and in the northern Adriatic region. Pure Appl. Geophys. 166: 1303-1318

Sternai P, Herman F, Champagnac J-D, Fox M, Salcher B, Willett SD (2012) Preglacial topography of the European Alps. Geology 40: 1067-1070 
Accepted Manuscript published at Elements Vol. 17, pp. 41-46

(DOI: 10.2138/gselements.17.1.41)

Sternai P, Herman F, Valla PG, Champagnac JD (2013) Spatial and temporal variations of glacial erosion in the Rhône valley: implications for relief development and sediment production. Earth Planet. Sci. Lett. 368: 119-131

Sternai P, Sue C, Husson L, Serpelloni E, Becker TW, Willett SD, Faccenna C, Di Giulio A, Spada A, Jolivet L, Valla PG, Petit C, Nocquet J-M, Walpersdorf, Castelltort S (2019) Present-day uplift of the European Alps: Evaluating mechanisms and models of their relative contributions. Earth-Science Reviews 190: 589-604

Valla PG, Shuster DL, van der Beek PA (2011) Significant increase in relief of the European Alps during mid-Pleistocene glaciations. Nature Geoscience 4, 688-692

Vernon AJ, van der Beek PA, Sinclair HD, Rahn MK (2008) Increase in late Neogene denudation of the European Alps confirmed by analysis of a fission-track thermochronology database. Earth Planet. Sci. Lett. 270: 316-329

Whipple KX (2009) The influence of climate on the tectonic evolution of mountain belts. Nature Geoscience 2: 97-104

Zachos J, Pagani M, Sloan L, Thomas E, Billups K (2001) Trends, rhythms, and aberrations in global climate $65 \mathrm{Ma}$ to present. Science 292: 686-693

Zhao L, Paul A, Malusà MG, Xu X, Zheng T, Solarino S, Guillot S, Schwartz S, Dumont T, Salimbeni S, Aubert C (2016) Continuity of the Alpine slab unraveled by high-resolution P wave tomography. J. Geophys. Res. 121: 8720-8737 